\title{
Absence of Association between the Incidence of BK Virus and Sporadic Creutzfeldt-Jakob Disease
}

\author{
Byung-Hoon Jeong Jung-Hwa Lee Han-Jeong Cho Yong-Sun Kim \\ Ilsong Institute of Life Science, Hallym University, Gyeonggi-do, Republic of Korea
}

\section{Key Words}

Polyomavirus - Genotypes · BK virus · Prion disease .

Creutzfeldt-Jakob disease $\cdot$ Phylogenetic tree

\begin{abstract}
Background: Many studies suggest that the virus-like particles are required for the infection of Creutzfeldt-Jakob disease (CJD). Objective: To determine the relationship between BK polyomavirus (BKV) and sporadic CJD. Materials and Methods: We investigated the prevalence of $B K V$ in urine samples from 94 sporadic CJD patients and 54 other neurological disease (OND) patients using polymerase chain reaction. Results: BKV DNA was detected in $16(17 \%)$ and 9 (16.7\%) urine samples from sporadic CJD and OND patients, respectively. There was no significant difference in the incidence of BKV infection between Korean sporadic CJD and OND patients $(p=0.9558)$. In order to investigate the genotypes of BKV, we analyzed 22 BKV isolates obtained from Korean patients by DNA sequencing and nucleotide sequence analysis. Three distinct subtypes, namely I, III, and IV, were found in $66.7,22.2$, and $11.1 \%$ of 9 BKV isolates from OND patients, whereas subtypes I and IV were detected in 76.9 and $23.1 \%$ of $13 \mathrm{BKV}$ isolates from sporadic CJD patients. Interestingly, subtype III was not detected in sporadic CJD patients.
\end{abstract}

\section{KARGER}

(c) 2013 S. Karger AG, Basel

0300-5526/13/0563-0184\$38.00/0

E-Mail karger@karger.ch

www.karger.com/int
Significant differences in the frequency of BKV genotypes were not observed between sporadic CJD and OND patients. Conclusions: These results indicate that BKV may not play an important role in the pathogenesis of prion diseases.

Copyright $\odot 2013$ S. Karger AG, Basel

\section{Introduction}

Transmissible spongiform encephalopathies or prion diseases, such as scrapie in sheep, Creutzfeldt-Jakob disease (CJD) and kuru in humans, and bovine spongiform encephalopathy in cattle, are fatal infectious neurodegenerative diseases, which are characterized by the accumulation of an abnormal form of prion protein $\left(\mathrm{PrP}^{\mathrm{Sc}}\right)$, spongiform neurodegeneration, neuronal cell loss and astrogliosis in the brain [1]. CJD is classified into three types: sporadic, acquired, and inherited forms. The most common form of CJD is sporadic CJD, which occurs worldwide with an incidence rate of

B.-H.J. and J.-H.L. contributed equally to this work. 
about 1 in a million per year. Although the conversion process of cellular prion protein $\left(\mathrm{PrP}^{\mathrm{C}}\right)$ to $\mathrm{PrP}^{\mathrm{Sc}}$ is the critical molecular event in the pathogenesis of sporadic CJD, the precise pathogenic mechanism and the nature of infectious agent(s) of sporadic CJD still remain unknown.

According to the protein-only hypothesis which is the most favored hypothesis, misfolded $\mathrm{PrP}^{\mathrm{Sc}}$ itself is the infectious agent and certain co-factors including protein $\mathrm{X}$ may play an important role in the transition process of $\mathrm{PrP}^{\mathrm{C}}$ to $\mathrm{PrP}^{\mathrm{Sc}}$ [2]. Based on the virus theory, this infectious agent shows many essential biological and physical characteristics of viruses such as symbiotic and classical pathogenic viruses and can establish a long-term persistent infection without causing the neurodegenerative disorder for a few decades [3]. It has been reported that 20to $35-\mathrm{nm}$ virus-like particles and tubulofilamentous virus-like particles termed nemavirus have been found in transmissible spongiform encephalopathy-infected brains [4-9]. The intracellular 25-nm virus-like particles were observed in cells infected with scrapie and CJD agents $[10,11]$. Herpes simplex virus (HSV) encephalitis has been reported as an initial presentation of CJD [12, 13]. Of 25 CJD patients, 3 had intrathecally synthesized antibodies against HSV in the cerebrospinal fluid and 2 against varicella zoster [14]. Also, DNA can convert $\operatorname{PrP}^{\mathrm{C}}$ into the $\beta$-sheet conformation [15] and circular DNA sequences co-purified with infectivity in scrapie and CJD [3]. Our previous studies showed that endogenous murine leukemia virus titer was increased in the brain of senescence-accelerated mouse by the scrapie infection and the incidence rate of human endogenous retroviruses in cerebrospinal fluids from CJD patients was significantly higher than other neurological disease (OND) patients and normal controls $[16,17]$.

The BK polyomavirus (BKV), which is a member of the polyomavirus genus, can coexist asymptomatically within the human body including brain [18]. The genome of approximately $5.1 \mathrm{~kb}$ circular DNA in length and the virion of about $40 \mathrm{~nm}$ in diameter are relatively smaller than other double-stranded viruses. Such properties prompted us to examine the incidence of BKV from urine samples of sporadic CJD patients.

In this paper, we investigated the relationship between BKV and sporadic CJD. In order to examine the incidence of BKV in Korean sporadic CJD and OND patients, we screened urine samples from 94 sporadic CJD and 54 OND patients and analyzed the genotype of BKV isolates.

BK Virus in Sporadic Creutzfeldt-Jakob Disease
Table 1. Characteristics of sporadic CJD patients and OND patients

\begin{tabular}{lcc}
\hline & $\begin{array}{l}\text { Sporadic } \\
\text { CJD }\end{array}$ & OND \\
\hline $\begin{array}{l}\text { Number of subjects } \\
\text { Gender }\end{array}$ & 94 & 54 \\
$\quad$ Male & 42 & 23 \\
& $(44.7 \%)$ & $(42.6 \%)$ \\
Female & 52 & 31 \\
& $(55.3 \%)$ & $(57.4 \%)$ \\
Mean age $( \pm S D)$ at disease onset, years & $65.9 \pm 7.9$ & $66.2 \pm 10.4$ \\
Male & $65.5 \pm 7.9$ & $68.3 \pm 9.2$ \\
$\quad$ BKV-positive & $68.0 \pm 2.0$ & $67.0 \pm 6.1$ \\
BKV-negative & $65.3 \pm 8.2$ & $68.6 \pm 10.0$ \\
Female & $66.2 \pm 8.0$ & $64.6 \pm 11.1$ \\
$\quad$ BKV-positive & $68.6 \pm 8.1$ & $59.5 \pm 14.4$ \\
BKV-negative & $65.4 \pm 7.8$ & $65.3 \pm 10.7$ \\
\hline
\end{tabular}

\section{Material and Methods}

\section{Urine Samples}

Urine samples were collected from 94 sporadic CJD and 54 OND patients between January 2002 and December 2007. We used previously established criteria [19] for diagnosis of sporadic CJD in Korea. The sporadic CJD cases in Korea have been reported previously [20-22]. The study was approved by the Ethical Committee of Hallym University Sacred Heart Hospital and informed consent was given by all subjects or their caregivers. All urine samples were frozen at $-70^{\circ}$ until used. The characteristics of subjects are shown in table 1.

\section{DNA Extraction}

$40 \mathrm{ml}$ of urine was centrifuged at $1,300 \mathrm{~g}$ for $10 \mathrm{~min}$ at $4^{\circ}$ to generate pellets. The pellet was dissolved in $1.3 \mathrm{ml} 10 \mathrm{~mm}$ Tris- $\mathrm{HCl}$ ( $\mathrm{pH}$ 7.6) and $10 \mathrm{mM}$ EDTA, and digested with $100 \mu \mathrm{g} / \mathrm{ml}$ proteinase $\mathrm{K}$ in the presence of $0.5 \%$ SDS. The mixture was incubated at $56^{\circ}$ for $1 \mathrm{~h}$. DNA was extracted from the digest with phenol saturated with $10 \mathrm{mM}$ Tris- $\mathrm{HCl}$ and chloroform-isoamyl alcohol (24:1, v/v) and then recovered by $5 \mathrm{M} \mathrm{NaCl}$ and cold ethanol and centrifuged at $30,000 \mathrm{rpm}$ for $30 \mathrm{~min}$ at $4^{\circ}$. The pellet was dissolved in $80 \mu \mathrm{l}$ of sterilized water and used for polymerase chain reaction (PCR).

\section{PCR Analysis}

The DNA extracted from the urine was used to amplify BKV DNA. The 287-bp VP1 region of BKV was amplified by PCR using primers BKV1 and BKV2. Primer BKV1 (5'-CAAGTGCCAAAACTACTAAT-3') spanned nucleotides 1630-1649 of the BKV genome and primer BKV2 (5'-TGCATGAAGGTTAAGCATGC-3') spanned nucleotides 1937-1956 [23]. The PCR reagents contained $50 \mathrm{pmol}$ of each primer, $5 \mu \mathrm{l}$ of $10 \times$ Taq DNA polymerase buffer, $1.5 \mathrm{mM} \mathrm{MgCl}_{2}, 0.2 \mathrm{mM}$ of the dNTP mixture, and 2.5 units of Taq DNA polymerase (Promega). The PCR conditions were as follows: an initial denaturation step of $94^{\circ}$ for $3 \mathrm{~min}, 40$ cycles of $94^{\circ}$ for $30 \mathrm{~s}, 56^{\circ}$ for $30 \mathrm{~s}$, and $72^{\circ}$ for $2 \mathrm{~min}$ and a final extension at $72^{\circ}$ for $10 \mathrm{~min}$. The PCR products were separated on a $1.2 \%$ agarose gel and visualized with ethidium bromide staining under UV light. 
Table 2. Summary of BKV prevalence in Korean sporadic CJD patients and OND patients

\begin{tabular}{|c|c|c|c|c|}
\hline \multirow[t]{2}{*}{$\begin{array}{l}\text { Subject } \\
\text { groups }\end{array}$} & \multirow{2}{*}{$\begin{array}{l}\text { Urine } \\
\text { samples } \\
\text { examined, } \\
\mathrm{n}\end{array}$} & \multirow{2}{*}{$\begin{array}{l}\text { BKV DNA- } \\
\text { positive } \\
\text { samples, n } \\
(\%)\end{array}$} & \multicolumn{2}{|c|}{$\begin{array}{l}\text { BKV-positive number/total } \\
\text { number of individuals (\%) }\end{array}$} \\
\hline & & & male & female \\
\hline OND & 54 & 9 (16.7) & $5 / 23(21.7)$ & $4 / 31(12.9)$ \\
\hline Sporadic CJD & 94 & $16(17.0)$ & $3 / 42(7.1)$ & $13 / 52(25.0)$ \\
\hline
\end{tabular}

Nucleotide Sequencing Analysis

The PCR products were purified for sequencing using a PCR purification kit (Qiagen). The DNA sequencing was carried out on an ABI 377 automatic sequencer using a Taq dideoxy terminator cycle sequencing kit (ABI). Nucleic acid sequences were assembled and edited using a combination of the ABI 377 DNA Sequencer Data Analysis Program and Sequence Navigator Software.

\section{Statistical Analysis}

Statistical analysis was performed using the SAS 8.2 software (SAS Institute, Inc.). Statistical parameters were analyzed by the $\chi^{2}$ test or Fisher's exact test.

\section{Phylogenetic Analysis}

A neighbor-joining (NJ) phylogenetic tree was constructed using the Clustal W program and the TreeView 1.4 program. Divergences were estimated by the two-parameter method. The bootstrap test was applied to estimate the confidence of the branching patterns of the NJ tree.

\section{Results}

\section{Detection of BKV DNA in Korean Sporadic CJD}

Patients

The general characteristics of the sporadic CJD patients and OND patients are shown in table 1. Urine samples were collected from 94 Korean CJD (mean age 65.9 years) and 54 OND patients (mean age 68.3 years). The mean age of BKV-positive sporadic CJD patients (65.5 years) in males was very similar to that of OND patients (68.3 years), whereas the mean age of BKV-positive sporadic CJD patients (68.6 years) in females was higher than that of OND patients (59.5 years) (table 1). To detect the presence of $\mathrm{BKV}$, urine samples were screened by PCR using BKV1 and BKV2 primers. BKV DNA was detected in $16(17.0 \%)$ of 94 Korean CJD patients and $9(16.7 \%)$ of 54 OND patients (table 2). The detection rate of BKV was not significantly different in urine samples of sporadic CJD patients from those of OND patients $(\mathrm{p}=0.9558)$. We have also examined whether there are significant dif-
Table 3. Incidence of subtypes of BKV in sporadic CJD patients and OND patients in South Korea

\begin{tabular}{lcrllll}
\hline $\begin{array}{l}\text { Subject } \\
\text { groups }\end{array}$ & $\begin{array}{l}\text { BKV isolates } \\
\text { examined, n (\%) }\end{array}$ & \multicolumn{4}{l}{$\begin{array}{l}\text { Isolates classified as indicated } \\
\text { subgroup, }\end{array}$} \\
\cline { 3 - 6 } & & I $\%)$ & II & III & IV \\
\hline OND & $9(100)$ & $6(66.7)$ & 0 & $2(22.2)$ & $1(11.1)$ \\
Sporadic CJD & $13(100)$ & $10(76.9)$ & 0 & 0 & $3(23.1)$
\end{tabular}

ferences in the prevalence of BKV DNA between CJD and OND patients based on gender. There was no significant difference in BKV prevalence between CJD and OND patients in men $(\mathrm{p}=0.1193)$ as well as in women ( $\mathrm{p}=$ 0.2631 ). This result suggests that the prevalence of BKV is not associated with sporadic CJD in the Korean population.

\section{BKV Subtypes in Korean Sporadic CJD Patients}

To further characterize the genotypes of BKV detected in urine samples from Korean sporadic CJD and OND patients, we sequenced the 287-bp typing region of BKV DNA from $22 \mathrm{BKV}$ isolates. The frequency of BKV subtypes in the sporadic CJD and OND patients is shown in table 3. The BKV-positive OND patients were classified into three subtypes, namely I, III, and IV, which were detected in $66.7,22.2$, and $11.1 \%$, respectively. However, subtypes I and IV were detected in 76.9 and $23.1 \%$ of BKV-positive sporadic CJD patients, respectively. Interestingly, subtype III was not detected in sporadic CJD patients. In addition, subtype II was not detected in either OND or sporadic CJD patients. There is no significant difference in type frequency of BKV between Korean sporadic CJD and OND patients $\left(\chi^{2}=0.0031, p=0.9558\right)$. These results indicate that sporadic CJD may be not associated with BKV subtypes.

In order to identify the combined effects of BKV and prion protein gene $(P R N P)$ on the pathogenesis of prion disease, BKV-positive data was stratified with PRNP codon 129 or with codon 219 genotypes (table 4 ). We found no significant differences in the frequency of BKV according to PRNP codon 129 or 219.

\section{Phylogenetic Analysis of BKV Isolates Based on DNA Sequences}

In order to investigate the phylogeny of BKV isolates, a phylogenetic tree was constructed using the $\mathrm{NJ}$ method from the DNA sequences of $22 \mathrm{BKV}$ isolates derived from urine samples of Korean patients with sporadic CJD and 
Table 4. Prevalence and genotyping of BKV according to PRNP codon 129 or 219 status

\begin{tabular}{|c|c|c|c|c|c|c|}
\hline \multirow{2}{*}{$\begin{array}{l}\text { BKV } \\
\text { subgroups }\end{array}$} & \multicolumn{3}{|c|}{ OND $(n=54)$} & \multicolumn{3}{|c|}{$\underline{\text { Sporadic CJD }(\mathrm{n}=94)}$} \\
\hline & $\begin{array}{l}\text { MM } \\
(\mathrm{n}=51)\end{array}$ & $\begin{array}{l}\text { MV } \\
(\mathrm{n}=3)\end{array}$ & $\begin{array}{l}\mathrm{VV} \\
(\mathrm{n}=0)\end{array}$ & $\begin{array}{l}\mathrm{MM} \\
(\mathrm{n}=94)\end{array}$ & $\begin{array}{l}\text { MV } \\
(\mathrm{n}=0)\end{array}$ & $\begin{array}{l}\mathrm{VV} \\
(\mathrm{n}=0)\end{array}$ \\
\hline PRNP 129 & 8 & 1 & 0 & $13^{\mathrm{a}}$ & 0 & 0 \\
\hline I & 6 & 0 & 0 & 10 & 0 & 0 \\
\hline II & 0 & 0 & 0 & 0 & 0 & 0 \\
\hline III & 1 & 1 & 0 & 0 & 0 & 0 \\
\hline \multirow[t]{2}{*}{ IV } & 1 & 0 & 0 & 3 & 0 & 0 \\
\hline & $\begin{array}{l}\mathrm{EE} \\
(\mathrm{n}=51)\end{array}$ & $\begin{array}{l}\text { EK } \\
(\mathrm{n}=3)\end{array}$ & $\begin{array}{l}\mathrm{KK} \\
(\mathrm{n}=0)\end{array}$ & $\begin{array}{l}\mathrm{EE} \\
(\mathrm{n}=94)\end{array}$ & $\begin{array}{l}\mathrm{EK} \\
(\mathrm{n}=0)\end{array}$ & $\begin{array}{l}\mathrm{KK} \\
(\mathrm{n}=0)\end{array}$ \\
\hline PRNP 219 & 9 & 0 & 0 & $13^{\mathrm{a}}$ & 0 & 0 \\
\hline $\mathrm{I}$ & 6 & 0 & 0 & 10 & 0 & 0 \\
\hline II & 0 & 0 & 0 & 0 & 0 & 0 \\
\hline III & 2 & 0 & 0 & 0 & 0 & 0 \\
\hline IV & 1 & 0 & 0 & 3 & 0 & 0 \\
\hline
\end{tabular}

${ }^{\text {a }}$ Numbers except for unclassified 3 BKV isolates.

OND and those of other $18 \mathrm{BKV}$ subtypes that were previously identified. According to the phylogenetic tree (fig. 1), of the $22 \mathrm{BKV}$ isolates, 2 were subtype III, 4 in the subtype IV, and 16 in the subtype I cluster which belong to subgroup Ic.

\section{Discussion}

In this study, we examined the BKV subtype profile based on gender from the urine samples of Korean sporadic CJD and OND patients (table 2). The incidence of BKV DNA excretion in Korean sporadic CJD patients was similar to that in OND patients. In addition, there was no significant difference in the genotype frequencies of BKV. Our results suggest that the incidence of BKV and the virus genotype are not associated with sporadic CJD.

The BKV is responsible for the renal dysfunction in immunosuppressed patients [24] and hemorrhagic cystitis in bone marrow transplant patients [25]. This virus is widespread in the human population [26], infecting asymptomatically during early childhood. It persists in the kidney throughout life [27]. The BKV genome consists of a circular double-stranded DNA. Genotype analysis of BKV revealed four distinct subtypes according to the DNA sequence variation of BKV VP1 region [28]. BKV subtype I is mainly distributed throughout the world. Based on the phylogenetic analysis, subtype I can be further subdivided

BK Virus in Sporadic Creutzfeldt-Jakob Disease into four subgroups, such as subgroups Ia, Ib- $1, \mathrm{Ib}-2$, and Ic [29-32]. BKV subtypes II and III are rarely distributed throughout the world. BKV subtype IV is mainly distributed in East Asians and divided further into six subgroups, such as subgroups IVa-1, IVa-2, IVb-1, IVb-2, IVc-1, and IVc-2. Similar to subtype I, each of subtype IV subgroups has a specific geographical distribution pattern [33]. The different subtypes of BKV are associated with human populations in different geographic regions [34].

In this study, the genotype distribution of $\mathrm{BKV}$ isolates found in urine samples of Korean CJD patients was compared with that of OND patients. There was no significant difference in the genotype distribution of BKV between OND and sporadic CJD (table 3 ). In addition, the distribution of BKV subtypes in controls is also very similar with that of OND and sporadic CJD patients in the Korean population. These results indicate that the distribution of BKV subtypes is not associated with the sporadic CJD.

Previously, the incidence of BKV in the urine of immunocompetent individuals in the Korean population has been reported [35]. 35\% of the examined immunocompetent individuals were BKV-positive. The incidence of BKV in Korean normal controls was higher than that in sporadic CJD patients $(17.0 \%, \mathrm{p}=0.0016)$ and $\mathrm{OND}$ patients $(16.7 \%, \mathrm{p}=0.0098)$. This result may be due to the difference of the storage period or the age of the cases analyzed.

The compartmentalized replication of BKV in different organs is shown in many studies that identify isolates from different organs with differences in the genomic sequences [36]. Rearrangements have also been identified for BKV in brain and cerebrospinal fluid [37]. The BKV is present in brain tumors with a controversial result [38]. Our negative result in urine samples may not be generalized to sporadic CJD. Therefore, further studies are required to confirm whether the incidence and genotypes of BKV are associated with sporadic CJD by examining various samples including brain and cerebrospinal fluid.

$P R N P$ plays a crucial role in conferring susceptibility to prion diseases. Polymorphisms of PRNP at codons 129 and 219 have been shown to be a genetic factor for sporadic CJD [39]. We investigated whether the combined effects between $P R N P$ polymorphisms and BKV subtypes are responsible for the susceptibility to sporadic CJD. When BKV subtypes were stratified by PRNP codons 129 or 219, no significant correlation was found between the distribution of BKV subtypes and PRNP polymorphisms (table 4).

In conclusion, we determined the relationship between BKV infection and sporadic CJD by examining the 
Fig. 1. Phylogenetic analysis of the BKV isolates from Korean CJD and OND patients. A NJ tree was constructed from Korean BKV isolates from this study and the reported BKV DNA sequences using the Clustal $\mathrm{W}$ and TreeView 1.4 program. The numbers at the nodes indicate bootstrap confidence levels obtained from 100 replicates. Only values greater than $50 \%$ are shown.

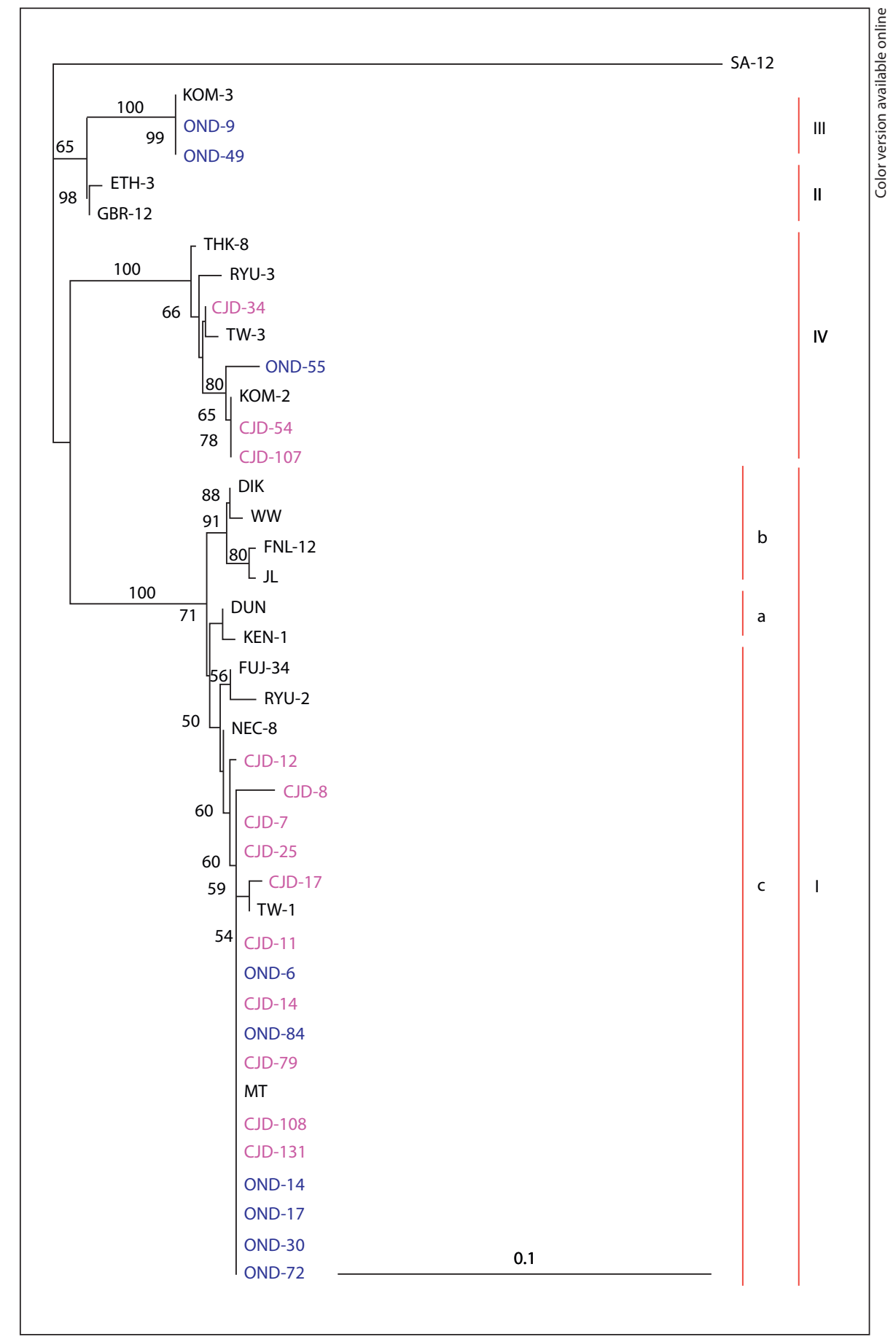

incidence rate and genotype of BKV from urine of Korean sporadic CJD patients. We found no correlation between the incidence of BKV infection and sporadic CJD. Also, there was no association in the frequency of BKV subtypes between Korean sporadic CJD and OND patients.

\section{Acknowledgments}

This study was supported by Basic Science Research Program through the National Research Foundation of Korea (NRF) funded by the Ministry of Education, Science and Technology (20120000308) and the National Research Foundation of Korea Grant funded by the Korean Government (NRF-2011-619-E0001). 


\section{References}

1 Prusiner SB: Molecular biology of prion disease. Science 1991;252:1515-1522.

- 2 Kim NH, Choi JK, Jeong BH, Kim JI, Kwon MS, Carp RI, Kim YS: Effect of transition metals $(\mathrm{Mn}, \mathrm{Cu}, \mathrm{Fe})$ and deoxycholic acid (DA) on the conversion of $\operatorname{PrP}^{\mathrm{C}}$ to $\operatorname{PrP}^{\text {res. }}$. FASEB J 2005; 19:783-785.

3 Manuelidis L: Nuclease-resistant circular DNAs copurify with infectivity in scrapie and CJD. J Neurovirol 2011;17:131-145.

-4 David-Ferreira JF, David-Ferreira KL, Gibbs CJ Jr, Morris JA: Scrapie in mice: ultrastructural observations in the cerebral cortex. Proc Soc Exp Biol Med 1968;127:313-320.

5 Bignami A, Parry HB: Aggregations of 35-nanometer particles associated with neuronal cytopathic changes in natural scrapie. Science 1971;171:389-390.

6 Sklaviadis T, Dreyer R, Manuelidis L: Analysis of Creutzfeldt-Jakob disease infectious fractions by gel permeation chromatography and sedimentation field flow fractionation. Virus Res 1992;26:241-254.

7 Narang HK: Evidence that single-stranded DNA wrapped around the tubulofilamentous particles termed 'nemaviruses' is the genome of the scrapie agent. Res Virol 1998;149:375-382.

8 Manuelidis L: Transmissible encephalopathies: speculations and realities. Viral Immunol 2003;16:123-139.

-9 Liberski PP, Jeffrey M: Tubulovesicular structures-the ultrastructural hallmark for transmissible spongiform encephalopathies or prion diseases. Folia Neuropathol 2004;42(suppl B):96-108.

10 Manuelidis L, Yu ZX, Barquero N, Mullins B: Cells infected with scrapie and CreutzfeldtJakob disease agents produce intracellular 25nm virus-like particles. Proc Natl Acad Sci USA 2007;104:1965-1970.

11 Manuelidis L: A 25-nm virion is the likely cause of transmissible spongiform encephalopathies. J Cell Biochem 2007;100:897-915.

$\checkmark 12$ Brecher K, Stopa EG, Kenney K: Concurrent herpes simplex virus encephalitis and Creutzfeldt-Jakob disease. J Neurol Neurosurg Psychiatry 1998;64:418-419.

13 Pollak L, Shabazov E, Mendlovic S, Rabey MJ: Herpes simplex encephalitis as an initial presentation of Creutzfeldt-Jakob disease. Isr Med Assoc J 2008;10:392-394.

14 Jacobi C, Arlt S, Reiber H, Westner I, Kretzschmar HA, Poser S, Zerr I: Immunoglobulins and virus-specific antibodies in patients with Creutzfeldt-Jakob disease. Acta Neurol Scand 2005;111:185-190.

15 Cordeiro Y, Machado F, Juliano L, Juliano MA, Brentani RR, Foguel D, Silva JL: DNA converts cellular prion protein into the $\beta$-sheet conformation and inhibits prion peptide aggregation. J Biol Chem 2001;276: 49400-49409.

16 Lee KH, Jeong BH, Jin JK, Meeker HC, Kim JI, Carp RI, Kim YS: Scrapie infection activates the replication of ecotropic, xenotropic, and polytropic murine leukemia virus $(\mathrm{MuLV})$ in brains and spinal cords of senescence-accelerated mice: implication of MuLV in progression of scrapie pathogenesis. Biochem Biophys Res Commun 2006;349:122-130.

17 Jeong BH, Lee YJ, Carp RI, Kim YS: The prevalence of human endogenous retroviruses in cerebrospinal fluids from patients with sporadic Creutzfeldt-Jakob disease. J Clin Virol 2010;47:136-142.

18 Elsner C, Dörries K: Evidence of human polyomavirus BK and JC infection in normal brain tissue. Virology 1992;191:72-80.

19 Zerr I, Pocchiari M, Collins S, Brandel JP, de Pedro Cuesta J, Knight RS, Bernheimer H, Cardone F, Delasnerie-Lauprêtre N, Cuadrado Corrales N, Ladogana A, Bodemer M, Fletcher A, Awan T, Ruiz Bremón A, Budka H, Laplanche JL, Will RG, Poser S: Analysis of EEG and CSF 14-3-3 proteins as aids to the diagnosis of Creutzfeldt-Jakob disease. Neurology 2000;55:811-815.

20 Jeong BH, Jeon YC, Lee YJ, Cho HJ, Park SJ, Chung DI, Kim J, Kim SH, Kim HT, Choi EK, Choi KC, Carp RI, Kim YS: Creutzfeldt-Jakob disease with the V203I mutation and M129V polymorphism of the prion protein gene $(P R N P)$ and a $17-\mathrm{kD}$ a prion protein fragment. Neuropathol Appl Neurobiol 2010;36:558563.

21 Jeong BH, Lee KH, Lee YJ, Yun J, Park YJ, Cho HJ, Kim YH, Cho YS, Choi EK, Carp RI, Kim YS: Absence of association between two HECTD2 polymorphisms and sporadic Creutzfeldt-Jakob disease. Dement Geriatr Cogn Disord 2011;31:146-151.

22 Yun J, Jin HT, Lee YJ, Choi EK, Carp RI, Jeong BH, Kim YS: The first report of RPSA polymorphisms, also called 37/67 kDa LRP/LR gene, in sporadic Creutzfeldt-Jakob disease. BMC Med Genet 2011;12:108.

23 Jin L, Gibson PE, Booth JC, Clewley JP: Genomic typing of BK virus in clinical specimens by direct sequencing of polymerase chain reaction products. J Med Virol 1993;41:11-17.

24 De Bruyn G, Limaye AP: BK virus-associated nephropathy in kidney transplant recipients. Rev Med Virol 2004;14:193-205.

25 Kinnaird AN, Anstead GM: Hemorrhagic cystitis and possible neurologic disease from $\mathrm{BK}$ virus infection in a patient with AIDS. Infection 2010;38:124-127.

26 Knowles WA: Propagation and assay of BK virus. Methods Mol Biol 2001;165:19-31.

27 Chesters PM, Heritage J, McCance DJ: Persistence of DNA sequences of BK virus and JC virus in normal human tissues and in diseased tissues. J Infect Dis 1983;147:676-684.

28 Luo C, Bueno M, Kant J, Martinson J, Randhawa P: Genotyping schemes for polyomavirus BK, using gene-specific phylogenetic trees and single nucleotide polymorphism analysis. J Virol 2009;83:2285-2297.

29 Yogo Y, Zhong S, Suzuki M, Shibuya A, Kitamura T: Occurrence of the European sub- group of subtype I BK polyomavirus in Japanese-Americans suggests transmission outside the family. J Virol 2007;81:13254-13258.

-30 Takasaka T, Goya N, Tokumoto T, Tanabe K, Toma H, Ogawa Y, Hokama S, Momose A, Funyu T, Fujioka T, Omori S, Akiyama H, Chen Q, Zheng HY, Ohta N, Kitamura T, Yogo Y: Subtypes of BK virus prevalent in Japan and variation in their transcriptional control region. J Gen Virol 2004;85:2821-2827.

31 Ikegaya H, Saukko PJ, Tertti R, Metsärinne KP, Carr MJ, Crowley B, Sakurada K, Zheng HY, Kitamura T, Yogo Y: Identification of a genomic subgroup of $\mathrm{BK}$ polyomavirus spread in European populations. J Gen Virol 2006;87:3201-3208.

-32 Zheng HY, Nishimoto Y, Chen Q, Hasegawa M, Zhong S, Ikegaya H, Ohno N, Sugimoto C, Takasaka T, Kitamura T, Yogo Y: Relationships between $\mathrm{BK}$ virus lineages and human populations. Microbes Infect 2007;9:204-213.

-33 Nishimoto Y, Zheng HY, Zhong S, Ikegaya H, Chen Q, Sugimoto C, Kitamura T, Yogo Y: An Asian origin for subtype IV BK virus based on phylogenetic analysis. J Mol Evol 2007;65: 103-111.

34 Zhong S, Randhawa PS, Ikegaya H, Chen Q, Zheng HY, Suzuki M, Takeuchi T, Shibuya A, Kitamura T, Yogo Y: Distribution patterns of BK polyomavirus (BKV) subtypes and subgroups in American, European and Asian populations suggest co-migration of BKV and the human race. J Gen Virol 2009;90:144-152.

35 Zhong S, Jeong BH, Ikegaya H, Kim YS, Xu Y, Zhu M, Chao Y, Suzuki M, Kitamura T, Homma Y, Yogo Y: Comparison of the distribution patterns of BK polyomavirus lineages among China, Korea and Japan: implications for human migrations in northeast Asia. Microbiol Immunol 2009;53:266-276.

36 Boldorini R, Allegrini S, Miglio U, Paganotti A, Veggiani C, Mischitelli M, Monga G, Pietropaolo V: Genomic mutations of viral protein 1 and $B K$ virus nephropathy in kidney transplant recipients. J Med Virol 2009;81: 1385-1893.

37 Stoner GL, Alappan R, Jobes DV, Ryschkewitsch CF, Landry ML: BK virus regulatory region rearrangements in brain and cerebrospinal fluid from a leukemia patient with tubulointerstitialnephritisandmeningoencephalitis. Am J Kidney Dis 2002;39:1102-1112.

- 38 Rollison DE, Utaipat U, Ryschkewitsch C, Hou J, Goldthwaite P, Daniel R, Helzlsouer KJ, Burger PC, Shah KV, Major EO: Investigation of human brain tumors for the presence of polyomavirus genome sequences by two independent laboratories. In J Cancer 2005; 113:769-774.

39 Jeong BH, Lee KH, Kim NH, Jin JK, Kim JI, Carp RI, Kim YS: Association of sporadic Creutzfeldt-Jakob disease with homozygous genotypes at $P R N P$ codons 129 and 219 in the Korean population. Neurogenetics 2005;6: 229-232. 